\title{
Rules to goals: emergence of new governance strategies for sustainable development
}

\section{Governance for global sustainability is undergoing a major transformation from rule-based to goal-based. But with no compliance measures, success will require an unprecedented level of coherency of action founded on new and reformed institutions nationally and internationally}

\author{
Norichika Kanie $^{1}\left(\mathbb{D} \cdot\right.$ David Griggs $^{2,3} \cdot$ Oran Young $^{4} \cdot$ Steve Waddell $^{5} \cdot$ Paul Shrivastava $^{6,7} \cdot$ Peter M. Haas $^{8}$. \\ Wendy Broadgate ${ }^{9}$. Owen Gaffney ${ }^{9,10}$. Csaba Körösi ${ }^{11}$
}

Received: 28 November 2018 / Accepted: 21 August 2019 / Published online: 6 September 2019

(c) The Author(s) 2019

\begin{abstract}
The Sustainable Development Goals (SDGs) and the Paris Agreement on climate are the key international agreements to deliver a sustainable future. They are a compromise between the scientifically necessary and politically possible to achieve global sustainability. Agreed in 2015, they constitute a radical departure for international policy with no precedents and are beginning to shape national policy, civil society and business decisions. We argue that these new frameworks represent the most important institutional innovation to emerge in recent years. They mark a shift away from international rule-making towards a system based on goal setting. This reflects a theory of societal steering or what we commonly think of as governance that differs sharply from mainstream regulatory systems by Pauwelyn et al. (Eur J Int Law 24:733-763, 2014). Given that achieving the Paris Agreement and the SDGs will require transformation of societies at all levels, it remains unclear how existing instruments, policies, and even institutions will adapt to this new global governance strategy. The key to success, we argue, will be "action coherence", whereby actions initiated to fulfill individual SDGs are coherent across efforts to achieve the full set of SDGs over the long run.
\end{abstract}

Keywords SDGs · Governance · Action coherency $\cdot$ Sustainable development

Handled by Osamu Saito, United Nations University Institute for the Advanced Study of Sustainability, Japan.

This paper is based on the outcome of the workshop "SynLink SDGs" co-hosted by Keio GESL, UNU-IAS, Earth System Governance Project and Future Earth SDG Knowledge Action Network, 5-7 March 2017, Glen Cove, New York, NY. Full report is available at http://www.earthsystemgovernance.org/wp-content/ uploads/2017/10/Report-of-Synlink-SDGs-Workshop.pdf.

Electronic supplementary material The online version of this article (https://doi.org/10.1007/s11625-019-00729-1) contains supplementary material, which is available to authorized users.

Norichika Kanie

kanie@sfc.keio.ac.jp

Extended author information available on the last page of the article

\section{What are the problems with the existing system?}

A rules-based approach to tackling problems involving public goods dominates national and international governance. The emphasis is on developing strong compliance mechanisms: regulations, monitoring, dispute resolution processes, and penalties for transgression (Chayes and Chayes 1995). While this strategy can perform well in solving problems like phasing out ozone-depleting substances, negotiations often become intractable. Even when agreements are reached, they may be so diluted they please no one. Even if the agreements are rather strong due to a sense of urgency, co-ordinated action by all states could be delayed or diluted over time. The Kyoto Protocol is a prime example of this where, following the US withdrawal, it took more than 10 years before a new agreement was reached. Stakeholders 
beyond nation states, such as multinational corporations, can be, or can perceive themselves to be, beyond effective control by the rule setters.

In examining ways to achieve action coherence, it is useful to consider the reasons behind "action incoherence". We have identified three major factors, though there may be others. First, government departments, company divisions, university faculties, and international institutions are commonly organized into discipline-, issue-, or sector-based silos to simplify decision-making. Second, systems are often designed to be competitive. Government departments compete for budget, businesses compete for market share, universities compete for research income and students, and NGOs compete for philanthropic funding. In a competitive system, it is difficult to form the partnerships necessary for managing synergies and trade-offs. Third, mechanisms for promoting co-operation across silos are under-developed. Constraints include time, effort, and money, since coherence requires time to meet, form partnerships, and understand an issue from multiple perspectives. Combined with a lack of commitment at the systemic level and inadequate resources, these constraints impede co-operation toward fulfilling all SDGs together. It is not surprising that we are already starting to see fragmentation and turf wars as organizations compete to take the lead internationally, nationally or locally in promoting a particular goal or target.

Friction between governance through goals and governance through rules is a common occurrence. Research on institutional interplay, inter-linkages, and orchestration provides useful hints for co-ordination based on a regulatory framework, but governance through goals requires actions beyond co-ordination. ${ }^{1}$ Some of the SDGs have rule-based governance arrangements already in place, such as those for energy, fresh water, oceans, and climate, ${ }^{2}$ whereas others lack any operational regimes. Effort to harmonize rule-based regimes with goal-based governance, or indeed goals without clear foundations, create profound operational difficulties as organized policy networks fight it out (e.g., advocates

\footnotetext{
1 Young, Oran R. 2002. The Institutional Dimensions of Environmental Change: Fit, Interplay, and Scale. Cambridge, MA: MIT Press, Oberthür, S., \& Gehring, T. (2006). Institutional Interaction in Global Environmental Governance: Synergy and Conflict among International and EU Policies. (S. Oberthür \& T. Gehring, Eds.). Cambridge, MA: MIT Press, Fukuda-Parr, Sakiko, Alicia Ely Yamin, and Joshua Greenstein. 2014. The Power of Numbers: A Critical Review of Millennium Development Goal Targets for Human Development and Human Rights. Journal of Human Development and Capabilities 15 (2-3): 105-117., Abbott, Kenneth W., and Duncan Snidal. 2009. Strengthening International Regulation Through Transnational New Governance: Overcoming the Orchestration Deficit. Vanderbilt Journal of Transnational Law 42: 501-578.

${ }^{2}$ United Nations, 2016, Global Sustainable Development Report 2016, Department of Economic and Social Affairs, New York, July.
}

of managed tropical timber harvesting vs. defenders of biological diversity). Developing a common grundnorm for sustainability may overcome these institutional hurdles. In the case of human rights, the Universal Declaration of Human Rights has provided a basis for developing a wide variety of individual rights as rules for the protection of those rights were developed and applied by states and by social activists (Simmons 2009; Sikkink 2011). Perhaps, a universal declaration on the global commons would help.

\section{Governance through goals}

"Governance through goals", by contrast to governance through rules, proceeds by engaging a broad set of stakeholders, including representatives of industrial sectors, cities, science, indigenous groups, and others, in identifying common challenges and setting broad targets. The process allows quick agreement on goals and targets at the expense of identifying prohibitions and compliance mechanisms. The theory of change is that once stakeholders sign up, they set priorities, aggregate resources, create the necessary institutions or adapt existing ones, and galvanize people and institutions to pursue the goals. It is no coincidence that such an approach reflects a number of lessons learned from analyzing effective management of common-pool resources, such as the need for defining users, inclusive decision-making processes as well as designing rules flexible enough to adapt to local needs and conditions (Ostrom et al. 1999).

\section{Challenge of action coherence}

The SDGs provide normative principles to follow and a common direction to pursue, and they legitimize this direction. They provide a clear rationale and rallying points for a more coherent approach as well as scope for identifying stakeholders to be included in considering a particular problem. They provide an opportunity to respond to clearly identified major problems through multi-stakeholder involvement, a transparent reporting process through co-ordination in national development, and other stakeholder plans. The SDGs are broad, embracing the three pillars of sustainable development: economic prosperity, social well-being, and environmental protection. This comprehensive approach raises classic interaction challenges of complex systems. Goals are not established systematically, and if one looks at one goal only without considering others, achievement of the other goals could be impeded. Therefore, actions to attain the goals need to be coherent and this is important to achieve a set of goals. Feeding 9 billion people (Goal 2) could result in deforestation (Goal 15) and increased greenhouse gas emissions, accelerating climate change (Goal 13). On the other 
hand, there may be synergies: providing quality education for all (Goal 4) may foster gender equality (Goal 5), since educating girls provide them with more equal opportunities.

Nilsson et al. (2016) have developed a framework to analyze seven different types of interactions among the SDG targets (Nilsson et al. 2016). This framework facilitates a greater understanding of the, often unintended, consequences of action towards one SDG on another SDG(s). Therefore, a coherent approach to attaining the goals is essential, but this is problematic in practice-many institutions attempting to achieve the goals focus on just a small subset. Few outside of nation states or local governments currently have the ability and awareness to take on all.

Achieving coherence in managing the many and complex interactions among the SDGs requires nurturing "system-awareness" to realize synergies, avoid unproductive conflicts, respond to gaps in effort, and overcome inertia (Stafford-Smith et al. 2016). We use the term "action coherence" to refer to the adoption of smart governance mechanisms to maximize synergies and minimize trade-offs that go beyond co-ordination of siloed institutions and governmental or intergovernmental actions. Action coherency is action oriented by addressing multiple related issues in a sustainable manner through stakeholder deliberations.

\section{Four properties required for goal-based governance of the SDGs}

The following four properties are considered required for goal-based governance of the SDGs. These four are not necessarily an exclusive list, but are considered as the key properties considering the characteristics and the governance system for the SDGs (Kanie and Biermann 2017). Three of them are drawn from the principles and approaches embedded in the 2030 Agenda for Sustainable Development, and the fourth aims to respond to the characteristics of the Anthropocene world in which the SDGs are expected to perform. (Griggs et al. 2013).

1. Establish effective governance systems for cross-silo interaction. A common purpose of long-term integrative effort is required, rather than sector-based, short-term initiatives. At a national level, establishing laws that promote SDGs would be a good first step to provide a legal basis for the new goal-oriented approach. Mechanisms for integration across silos (joint committees, multi-silo funding, silo crossover innovation programs, matrix responsibility structures, and cross-silo information sharing) need to be adopted. Sweden's approach to the SDGs where the SDGs lie in the development ministry but that minister is deputy prime minister is one positive example.
2. Set goals and concrete targets first, then backcast from the future desired state to the current situation, and measure progress. Often targets are set as incremental improvements on present conditions. Setting goals based on what is necessary rather than what is immediately possible will help spur the required levels of innovation to achieve them. Policymakers and expert groups often assume a default of linear progress (e.g., IEA energy scenarios) when exponential progress is plausible (e.g., renewable's share of primary energy globally is increasing exponentially, doubling every 5.5 years) (Rockström et al. 2017) — a pace consistent with the Paris Agreement.

3. Encourage highly participatory and deliberative, reflective, transcendent approaches. All organizations and sectors must engage actively as partners rather than simply being consulted or directed. This brings new actors into governance roles. The effort must provide a place for deliberative discussions and piloting solutions. These spaces would include digital space for wide participation, ideological broadening of deliberations, and genuine inclusion of diverse and new voices in institutional deliberations and decision-making fora.

4. Enhance awareness of emergent properties of societies and the global economy. The Anthropocene-the age of humanity - is defined by speed, scale, connectivity, and surprise. To respond to this rapidly changing landscape, there is a need for greater flexibility and agility in decision-making and policy. The new ways that human and physical systems interact on a global scale requires new patterns of behavior (including action coherence) such as increased collaboration and orchestration between multiple groups of non-state actors.

\section{Transforming the system}

Within national governments, SDG implementation tends to be championed by a single ministry, and responsibilities for individual targets are divided up. Japan's SDGs Implementation Plan lists around 140 policies, each of which is administered by an individual government body. Co-ordination mechanisms may develop, but action coherency has not yet emerged. There are instances of new institutional frameworks emerging to address SDG implementation (Property 1, 4). At a local level, in Japan's first national SDGs Award winning Shimokawa city, authority is revitalizing local economies and overcoming population decline by focusing on their principal resource, forestry. Their population is becoming stable with aged population decreasing from $51.6 \%$ in 2009 to $27.6 \%$ in 2016 . Now, the city, the governing authority is adopting long-term strategies inspired by the SDGs (Property 2). They are introducing indicators to measure the 
distance to reach the targets, and aiming for scaling up successful goal attainment through learning (Property 3 ). Goals can be reset at regular intervals to reflect new learning and experience (Kanie and Biermann 2017; Young 2017). As a first step to create action coherency, Cabinet Office has generated a 500 million Yen budget for FY 2018 to support local governments' policy actions to simultaneously address three dimensions of sustainable development under a new "SDGs action plan 2018".

In other parts of the world, Brazil and Costa Rica have started to align their national development plans and the 2030 Agenda (Property 2). Belgium and Kenya have prepared national framework strategies for the implementation of the SDGs (Property 2). In Kenya, all public institutions are expected to mainstream SDGs into their plans (Property $1,2)$. Denmark is measuring the progress of their 37 targets in the SDGs national action plan (Property 2). ${ }^{3}$

The private sector is engaging through networks like the World Business Council for Sustainable Development or We Mean Business, with some limited success (Property 3, 4). Several high-profile multinationals have become strong advocates, internalizing the SDGs into their management (e.g., Glaxosmithkline, Roche, Unilever, BASF and Volvo) (Property 2, 3, 4). These first movers see the SDGs as a business opportunity and a way of reducing reputational, management and other risks. However, such measures also may signal a shift in mindset where businesses accept a new responsibility for the state of the Earth system.

Internationally, the UN High-Level Political Forum (HLPF) has a mandate to co-ordinate and monitor SDG progress. It is ironic that while the SDGs require an integrated, multi-stakeholder approach, the HLPF displays none of these characteristics (Bernstein 2017). To consider implementation of the SDGs as an indivisible whole, the HLPF must be broadened, strengthened, and granted increased resources to build capacity and knowledge and to review national efforts, in particular between countries at a similar level of economic development (Property 1,3).

Assessing progress on a regular basis is central to HLPF's work. Absent an effective mechanism through which the world's experts periodically assess progress, highlight issues, and project potential progress into the future, we cannot effectively monitor progress, direct resources, and change course as needed, key elements of Property 4.

The move from rule-based international governance to governance through goals is a response to decades of deadlock and intransigence. International governance has entered a brave new world with a 15-year experiment to deliver all goals simultaneously on a planetary scale. This will require an unprecedented level of co-operation and co-ordination, creating innovative coherent actions in an increasingly fractured geopolitical environment. Systematic evaluation of the governance system through, for example, enhanced Global Sustainable Development Reports and not just by a set of global indicators, would be useful to measure the governance progress over the period.

Open Access This article is distributed under the terms of the Creative Commons Attribution 4.0 International License (http://creativeco mmons.org/licenses/by/4.0/), which permits unrestricted use, distribution, and reproduction in any medium, provided you give appropriate credit to the original author(s) and the source, provide a link to the Creative Commons license, and indicate if changes were made.

\section{References}

Bernstein S (2017) In: Kanie and Biermann (eds) The United Nations and the governance of sustainable development goals. pp. 213-239

Chayes A, Chayes AH (1995) The new sovereignty: compliance with international regulatory agreements. Harvard University Press, Cambridge

Griggs DJ, Stafford-Smith M, Gaffney O, Rockstrom J, Ohman M, Shyamsundar P, Steffen W, Glaser G, Kanie N, Noble I (2013) Sustainable Development Goals for people and planet. Nature 495:305

Kanie N, Biermann F (eds) (2017) Governing through goals: sustainable development goals as governance innovation. MIT Press, Cambridge

Nilsson M, Griggs D, Visbeck M (2016) Map the interactions between sustainable development goals. Nature 534:320

Ostrom E, Burger J, Field CB, Norgaard RB, Policansky D (1999) Revisiting the commons: local lessons, global challenges. Science 284(5412):278-282

Pauwelyn J, Wessel RA, Wouters J (2014) When structures become shackles: stagnation and dynamics in international lawmaking. Eur J Int Law 25:733-763

Sikkink K (2011) The justice cascade. Norton, New York

Simmons BA (2009) Mobilizing for human rights. Cambridge University Press, Cambridge

Stafford-Smith M, Griggs D, Gaffney O, Ullah F, Reyers B, Kanie N, Stigson B, Shrivastava P, Leach M, O'Connell D (2016) Integration: the key to implementing the sustainable development goals. Sustain Sci. https://doi.org/10.1007/s11625-11016-10383-11623

Young OR (2017) In: Kanie and Biermann (eds) Conceptualization: goal setting as a strategy for earth system governance

Publisher's Note Springer Nature remains neutral with regard to jurisdictional claims in published maps and institutional affiliations.

\footnotetext{
${ }^{3}$ DSD, DESA, United Nations, Synthesis of Voluntary National Reviews 2017 (2017). https://sustainabledevelopment.un.org/content/ documents/17109Synthesis_Report_VNRs_2017.pdf.
} 


\section{Affiliations}

\section{Norichika Kanie $^{1}$ (1) $\cdot$ David Griggs $^{2,3} \cdot$ Oran Young $^{4} \cdot$ Steve Waddell $^{5} \cdot$ Paul Shrivastava $^{6,7} \cdot$ Peter M. Haas $^{8}$. Wendy Broadgate ${ }^{9}$. Owen Gaffney ${ }^{9,10}$. Csaba Körösi ${ }^{11}$}

1 Graduate School of Media and Governance, Keio University, 5322 Endo, Fujisawa 252-0882, Japan

2 Monash Sustainability Institute, Monash University, Monash, VIC 3800, Australia

3 Warwick University, Warwick, UK

4 University of California at Santa Barbara, Santa Barbara, CA, USA

5 NetworkingAction, Ottawa, Canada

6 The Pennsylvania State University, State College, PA, USA

7 ICN Business School, Nancy, France
8 Department of Political Science, University of Massachusetts, Amherst, MA, USA

9 Future Earth Swedish Hub, Stockholm, Sweden

10 Stockholm Resilience Centre, Stockholm University, Stockholm, Sweden

11 Office of the President of the Republic of Hungary, and United Nations Open Working Group On the SDGs Co-chair, Budapest, Hungary 